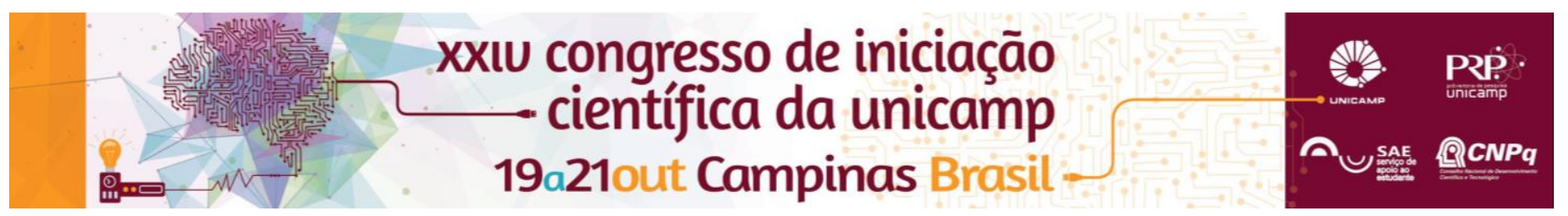

\title{
Análise Empírica do Impacto do Programa Bolsa Família na reeleição da Presidenta Dilma
}

\section{Victor C. Chotolli*}

\section{Resumo}

Estudos empíricos têm encontrado fortes evidências de que o Programa Bolsa Família melhorou as condições de vida das famílias beneficiadas, reduzindo a pobreza e tendo influência positiva na saúde e educação. Outro ponto é sobre influência em eleições, comprovada para as de 2006 e 2010, o PBF mostra influência positiva em relação as presidenciáveis do Partido dos Trabalhadores. O presente trabalho, portanto, procura comprovar, através de métodos econométricos, se há ou não influência do PBF na reeleição de Dilma em 2014, como houve nas outras eleições.

\section{Palavras-chave:}

Programa Bolsa Família, Reeleição, Dilma.

\section{Introdução}

O Programa Bolsa Família (PBF) é uma política social do governo federal para transferir renda de forma direta para famílias em situação de pobreza ou extrema pobreza. Há, porém, algumas condicionalidades para o recebimento dos benefícios: execução de exame prénatal, acompanhamento nutricional, acompanhamento de saúde e frequência escolar. O benefício básico é dado para famílias em extrema pobreza, mas há benefícios que são variáveis.

O intuito do PBF é garantir uma renda às famílias pobres e extremamente pobres. Inegavelmente, o programa é exitoso no sentido de combater a fome e a pobreza. Além disso, por meio de suas condicionalidades, é plausível que existam efeitos positivos sobre a saúde e educação. De fato, diversos estudos empíricos têm achado efeitos significativos do PBF sobre diversas faces do bem-estar social dos brasileiros.

Dentro da literatura empírica, outra questão levantada é a influência do PBF nas eleições presidenciais. Estudos comprovam influência positiva em 2006 e 2010 para o PT. O presente trabalho, com esse foco, buscou atestar a influência do PBF nas eleições de 2014 para a presidenta Dilma. Isso ocorreu através de modelos econométricos: regressões cross-section seguindo 0 método MQO usando dados em âmbito municipal.

Após a revisão de literatura, possíveis determinantes das eleições foram elencados e controlados pelos modelos para se observar a real influência do benefício na votação. A variável explicada foi a porcentagem de votos na presidenta no segundo turno das eleições de 2014. Renda e sua desigualdade, educação, saúde, economia, infraestrutura, população e urbanização, a porcentagem de voto no ano anterior da candidata e o próprio PBF, além de dummys para o governador do estado e regiões, foram levados em conta e controlados. Variáveis sobre as diferenças nos municípios entre 2010 e 2000 também foram consideradas para o modelo.

Um modelo com a votação de 2010 como variável dependente foi usado para meios de comparação.

\section{Resultados e Discussão}

Observou-se resultados conclusivos quanto aos determinantes das eleições de 2014 e seus impactos, apesar da presença de heterocedasticidade e não normalidade dos erros.

O PBF se mostrou influente para a eleição de Dilma, com alta significância, mas não foi a variável mais influente, ou seja, não se pode explicar os resultados da eleição apenas pela influência do PBF. A porcentagem de votos de Dilma na votação anterior e a frequência escolar foram as mais influentes positivamente. Outras grandes influências positivas foram a taxa de analfabetismo e o índice de Gini. Quanto as influências negativas para os votos em Dilma, a renda per capita e a mortalidade infantil são as maiores. Isso pode ser visto na figura 1 , onde se apresentam todas as variáveis significantes do modelo.

Figura 1. Gráfico das Estimativas de Modelo para 2014

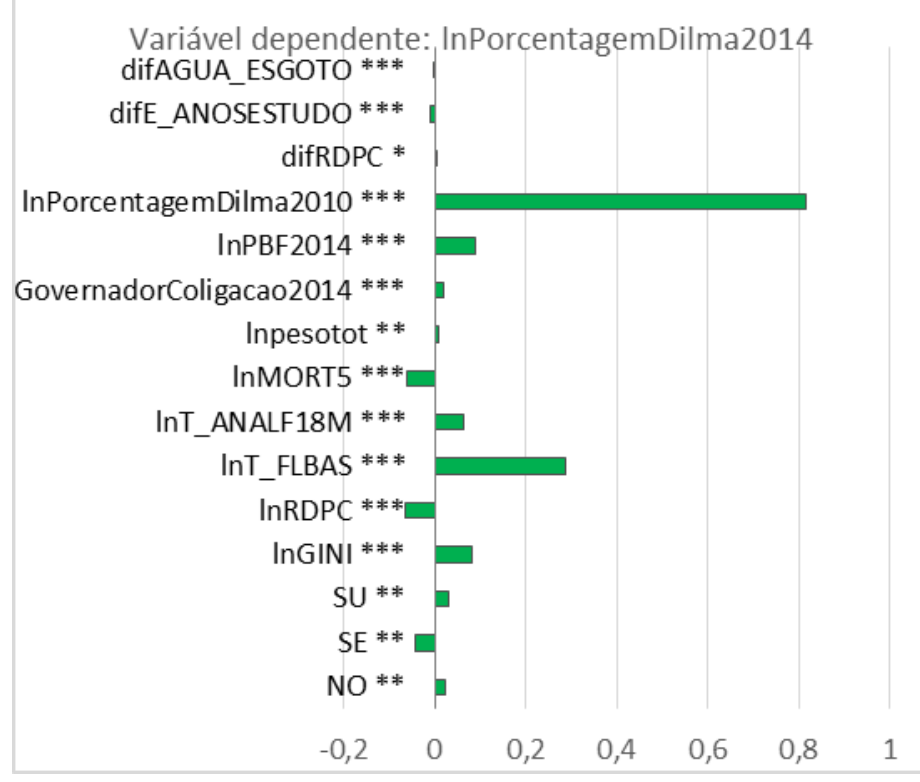

\section{Conclusões}

Concluiu-se que há influência positiva do PBF na eleição da presidenta Dilma em 2014, mas não com impacto suficiente para explicar o resultado das eleições. A fidelidade do eleitor foi, conclusivamente, mais importante para a reeleição da presidenta do que PBF, assim como a frequência escolar. Notou-se menor empatia dos mais favorecidos com o PT nas eleições.

\section{Agradecimentos}

Agradecer a todos que me ajudaram para o cumprimento do presente trabalho, principalmente meu orientador Marcelo Justus, e ao PIBIC (Programa Institucional de Bolsas de Iniciação Científica) pelo incentivo a pesquisa proposta. 